\title{
Norm Entrepreneurs Sidestep REDD+ in Pursuit of Just and Sustainable Forest Governance
}

\author{
Neil M. Dawson ${ }^{1, *}$, Michael Mason ${ }^{2}$ (D), Janet A. Fisher ${ }^{3}$, David Mujasi Mwayafu ${ }^{4}$, \\ Hari Dhungana ${ }^{5}$, Heike Schroeder ${ }^{1}$ and Mark Zeitoun ${ }^{1}$ \\ 1 School of International Development, University of East Anglia, Norwich Research Park, Norwich NR4 7TJ, \\ UK; h.schroeder@uea.ac.uk (H.S.); m.zeitoun@uea.ac.uk (M.Z.) \\ 2 Department of Geography and Environment, London School of Economics, London WC2A 2AE, UK; \\ M.Mason@lse.ac.uk \\ 3 School of Geosciences, University of Edinburgh, Edinburgh EH8 9YL, UK; Janet.Fisher@ed.ac.uk \\ 4 The Uganda Coalition for Sustainable Development, Kampala 27751, Uganda; \\ dmwayafu@ugandacoalition.or.ug \\ 5 The South Asian Institute for Advanced Studies, Kathmandu 44600, Nepal; hari@sias-southasia.org \\ * Correspondence: Neil.Dawson@uea.ac.uk; Tel.: +44-7960-545-370
}

Received: 23 February 2018; Accepted: 24 May 2018; Published: 25 May 2018

\begin{abstract}
This paper explores the dissonance between conceptions of justice among forest-adjacent communities and their representation in global forest policies, a persistent barrier to delivering just sustainability. We empirically track justice claims of rural villagers upwards through specific intermediaries or 'justice brokers': civil society, state, or private sector actors operating at local to international levels, who navigate different institutions to advance various social and ecological interests. We draw on interviews with 16 intermediaries in each of Nepal and Uganda and find that recognition of local values and practices such as customary tenure systems are key justice concerns of forest-adjacent communities in each country. However, intermediaries perceive a low likelihood of advancing those claims through national or international climate and forest policy debates, such as REDD+ (Reducing Emissions from Deforestation and forest Degradation), in large part because deliberations on justice are subordinated to concerns such as carbon accounting and arrangements for distributing monetary benefits. This suggests these policy processes must be modified to offer potential for transformational pathways. Intermediaries who pursued recognition justice issues developed innovative tactics in alternative forums. These 'norm entrepreneurs' adopted a suite of complementary strategies to attain influence, including: (1) formation of associations at the grassroots level; (2) media and advocacy campaigns through national coalitions to reach powerful international donors, and; (3) drawing on international support networks for advice, training and to influence national government. In both Uganda and Nepal these strategies were evidenced to enhance recognition for local values and practices.
\end{abstract}

Keywords: climate change; norm travel; power; environmental justice; participation; environmental policy; politics of scale; customary land tenure; indigenous peoples; cultural values

\section{Introduction}

A persistent disconnect exists between representations of justice, or equity, in global environmental governance and the type of justice ('social', 'environmental' or 'climate justice') sought by local communities and affected groups [1-5]. While some consider this perceived dissonance to represent an implementation gap that may be closed through capacity-building to enhance social and ecological sustainability, others point to a 'justice gap'-ideological differences between local justice concerns and 
the more constrained set of social objectives reflected in global policy [6-10]. If local communities deem environmental management to be unjust, the implications go beyond moral imperatives, i.e., protection of human rights, because these perceptions may also result in contestation or undermining of projects, limiting the likelihood that they effectively conserve ecosystems $[11,12]$. These links between social and environmental dimensions have long been acknowledged in sustainability science [13-15], such that the governance processes and power relations through which sustainability policies are determined at different scales have been highlighted as a key area for the generation of evidence to inform transformations to a more just sustainability [16-19]. It is increasingly important to acknowledge and close this justice gap due to the proliferation and accelerated implementation of globally-devised environmental governance impacting forest-dependent communities, including most recently the Sustainable Development Goals (e.g., SDG13 on climate and SDG15 on terrestrial habitats), and the Paris Agreement (e.g., Article 5 relating to forest conservation) [20,21].

A common source of contention for local communities regarding environmental management, particularly cultural minorities and Indigenous Peoples, is lack of recognition of their worldviews, identities, values, place attachments and practices in policy design and decision-making processes [22-25]. Significantly for forest governance, concerns often include values and practices pertaining to customary and communal tenure governing access to and use of land, places and resources. Recognition is considered one of three interrelated dimensions of environmental justice: the distribution of costs and benefits, the procedures through which decisions are made, and the recognition of different identities, values and practices in those processes and outcomes [26]. However, prominent justice theorists have emphasised the centrality of recognition among the other dimensions, suggesting any attempts to promote fairer distribution of costs and benefits or to enhance participation in decision-making procedures may be meaningless if recognition of the fundamental differences in values between groups is lacking $[27,28]$. The crucial implication is that if policies or programmes with social and environmental objectives are implemented without due regard to prominent recognition concerns, then they will create or reproduce injustices harming sections of local communities that may in turn lead to weak support and undermine both social and ecological outcomes [22]. Distinction between norms relating to different dimensions of justice (distribution, procedure and recognition) and the processes and interactions leading to their asymmetric representation in policy may therefore be critical for assessing the justice gap between policy and local perspectives.

In this article, we explore the perceptions of intermediaries regarding their role in mobilising justice-related norms upwards from the local level, and the opportunities and barriers they face in doing so in different forums. Intermediaries (otherwise termed justice brokers) are defined here as actors and institutions facilitating cross-scale communications amongst diverse actors on the identification, mobilisation and representation of justice-related norms. Intermediaries involved in our study comprised civil society, state and private sector actors in Uganda and Nepal, who seek to influence policies related to governance of forest and land, from local to international levels. Participants are described in more detail in Table 1. We concentrate specifically on norms relating to recognition of different values and practices held by communities living alongside forests in Uganda and Nepal. Our methodology, described in detail below, focuses on questions of which norms 'travel' between local contexts and national policy arenas and how that travel is facilitated or constrained, a growing approach to explore the politics of scale [29,30]. Alternative conceptual approaches may emphasise the nature of participation and representation, affording greater attention to the mechanisms of governance for a specific policy process [31,32]. Nepal and Uganda were selected due to the importance of natural resources to their socially-diverse rural populations and, despite their contrasting political contexts, the current prominence of political debate surrounding land and forest governance in each. More details of case-study countries and selection criteria are provided in Section 2. In the following section, we review literature on factors that may impede the travel or diffusion of norms from local to national and international levels and the characteristics of and actions employed by intermediaries who seek to mobilise local justice issues, with emphasis on recognition of 
cultural values and practices. Through interviews with a variety of intermediaries operating at various levels, we then detail the attempts of intermediaries in Nepal and Uganda to navigate the political space to promote recognition-based norms. We characterise the strategies, actions taken and forums engaged in by those justice brokers to influence policy, from the local level through to international policy negotiations, and describe some of the barriers to effective mobilisation of prominent local issues. We pay specific attention to the intermediaries' perceptions of and engagement in REDD+ (Reducing Emissions from Deforestation and forest Degradation, including conservation, sustainable management of forests and enhancement of forest carbon stocks) and climate policy forums to reveal the multiple barriers and deficiencies within those processes in Nepal and Uganda, meaning they fail to offer a platform to negotiate diverse values or provide opportunities to advance rights and justice for local communities. We detail the alternative strategies that some norm entrepreneurs among the intermediaries pursue to advance recognition and shape transformative pathways of change.

Table 1. Roles and scale of work of 16 intermediaries interviewed in Nepal and Uganda, based on participants' self-description. Organisation names have been removed to maintain anonymity.

\begin{tabular}{|c|c|c|c|}
\hline \multicolumn{2}{|l|}{ Uganda } & \multicolumn{2}{|l|}{ Nepal } \\
\hline Description of Role & Primary Scale of Work & Description of Role & Primary Scale of Work \\
\hline Civil society—human rights & Subnational & Civil society-indigenous rights & Subnational \\
\hline Civil society_land rights & Subnational & Civil society-indigenous rights & Subnational \\
\hline Civil society-land rights & National/International & Civil society-community forestry & Subnational \\
\hline $\begin{array}{l}\text { Government official-climate } \\
\text { change and forestry }\end{array}$ & National/International & $\begin{array}{l}\text { Civil society-environment and } \\
\text { development }\end{array}$ & Subnational \\
\hline $\begin{array}{c}\text { Civil society_climate change and } \\
\text { forestry }\end{array}$ & National/International & $\begin{array}{l}\text { Civil society-biodiversity } \\
\text { conservation }\end{array}$ & Subnational \\
\hline $\begin{array}{l}\text { Civil society-environment and } \\
\text { development }\end{array}$ & National & $\begin{array}{l}\text { Local government } \\
\text { official—biodiversity conservation }\end{array}$ & Subnational \\
\hline Private sector-commercial forestry & National & $\begin{array}{c}\text { Civil society-gender and } \\
\text { environment }\end{array}$ & National \\
\hline Civil society-poverty and rights & Subnational/national & $\begin{array}{l}\text { Civil society-indigenous rights } \\
\text { and climate change }\end{array}$ & National/International \\
\hline $\begin{array}{l}\text { Journalist-environment and } \\
\text { development }\end{array}$ & National & $\begin{array}{c}\text { Civil society-natural resource } \\
\text { conflict }\end{array}$ & National/International \\
\hline Local government official—forestry & Subnational & $\begin{array}{l}\text { Civil society-community forestry } \\
\text { and human rights }\end{array}$ & National/International \\
\hline $\begin{array}{c}\text { Local government } \\
\text { official—environment and } \\
\text { development }\end{array}$ & Subnational & $\begin{array}{l}\text { Government official-climate } \\
\text { change and forestry }\end{array}$ & National/International \\
\hline $\begin{array}{c}\text { Local government } \\
\text { official-environmental protection }\end{array}$ & Subnational & $\begin{array}{c}\text { Civil society-forestry and } \\
\text { development }\end{array}$ & National/International \\
\hline $\begin{array}{c}\text { Civil society-climate change and } \\
\text { development }\end{array}$ & Local to international & $\begin{array}{c}\text { Civil society-Dalit rights and } \\
\text { environment }\end{array}$ & National/International \\
\hline $\begin{array}{c}\text { Civil society - climate change and } \\
\text { development }\end{array}$ & Local to international & $\begin{array}{l}\text { Civil society_-biodiversity and } \\
\text { climate change }\end{array}$ & National/International \\
\hline $\begin{array}{l}\text { Civil society-sustainable } \\
\text { development and education }\end{array}$ & National/ international & $\begin{array}{l}\text { Journalist-environment and } \\
\text { development }\end{array}$ & National/International \\
\hline $\begin{array}{c}\text { Government } \\
\text { official-environmental } \\
\text { conservation }\end{array}$ & National/ international & $\begin{array}{c}\text { Private sector-environmental } \\
\text { consultancy }\end{array}$ & National/International \\
\hline
\end{tabular}

\subsection{Conceptualising Norm Travel}

As a well-functioning, inclusive and just policy process, global climate and forest governance would incorporate the diverse justice-related norms of remote local communities and any marginalised or vulnerable groups among them $[33,34]$. Justice-related norms represent shared understandings or commonly-held standards of how things should be and how things should be done [26]. Those norms can be diverse, complex and dynamic and are not simply diffused upwards or downwards 
between policymakers and local communities. Rather, for the justice-related norms to effectively travel from local level to national or even international levels, they must be acknowledged, mobilised and (re)presented in dynamic policy debates [29]. This brings to the fore the role of intermediaries (or justice brokers), comprising state, private sector and civil society actors and institutions who operate across levels to mobilise local struggles for justice and to represent local issues and perspectives in different forums, comprising both formal and informal interactions and decision-making negotiations at various levels to ensure local norms effectively inform policies (Figure 1, [30,35-38]).

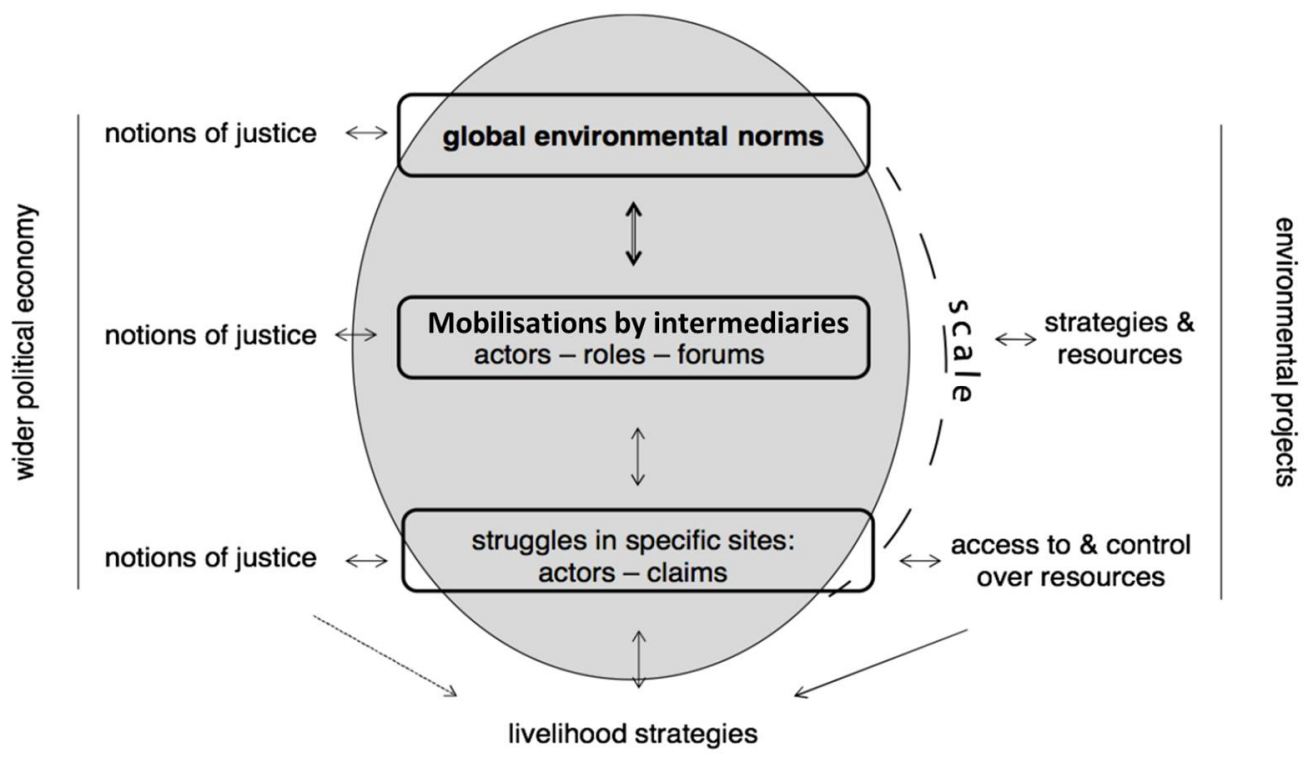

Figure 1. A conceptual framework for the travel of norms between local and global levels.

Intermediaries may range from those who follow or accept dominant norms, to activists and proponents of struggles who more actively seek to influence through advocacy, adaptation and effecting normative change. Numerous terms have been used to describe them and their work, including: imagineers, 'grassrooting vectors' [39], charismatic individuals or norm entrepreneurs [35]; we adopt here the latter term to describe those pursuing normative change. In the face of barriers to facilitating norm travel, the 'politics of scale' becomes critical as intermediaries make choices about the norms they choose to mobilise, and which they prioritise to articulate their concerns and make gains, the types of forums they seek to influence and the other actors they interact and cooperate with, for both their own personal and organisational objectives as well as those they seek to represent [40-42]. Yet the role of norm entrepreneurs has received limited scholarly attention or empirical study within the wider norm travel literature $[30,43]$. To account for the practices of these intermediaries, we therefore draw on related research on 'boundary work' in sustainable development, notably the interface between multiple sources of knowledge and multiple decision-making settings [44-46].

We view norms as dynamic and subject to continual negotiation such that, through intermediaries, new ones may emerge, evolve, be revised or stagnate [47]. To collaboratively promote the uptake of justice-related norms, intermediaries may share visions and responsibilities and connect strategies [35] to form coalitions of interest [40], temporary 'assemblages' [41] or transnational advocacy networks [48]. The forums they engage in are not restricted to formal policy processes but can also include various media, public protest and informal processes involving bargaining and lobbying where moments of influence may be realised as much as in formal arenas [49]. To further their norm promotion, intermediaries may move horizontally between different policy sectors, issues and arenas, and vertically across governance levels [50]. For example, Indigenous Peoples representatives successfully introduced human rights arguments into climate negotiations to attain greater policy acknowledgement [51]. In the face of national political constraints, some civil society intermediaries 
bypass national policy forums to engage with more progressive international networks such that those norms may then produce a subsequently greater influence or political pressure on domestic debates, which has been termed a 'boomerang effect' [52].

\subsection{Barriers to Effective Mobilisation and Upward Travel of Justice-Related Norms}

Norms relating to all dimensions of justice have gained increasing importance, spreading globally and vertically to all levels in global environmental governance [26]. Yet there are reasons to expect barriers to the effective upward travel ('governance uptake', in policy terms) of local norms. Notably, at national and subnational level, there may be considerable political constraints to voicing and mobilising certain notions of justice that go against dominant ways of thinking. For instance, in many countries indigeneity is not formally recognised and therefore articulating mobilisations in terms of recognition of rights for indigenous groups can have little impact or even result in repressive measures [53]. Research on boundary work for sustainable management of natural resources in developing countries has shown the asymmetric power relations often faced in the valuation of indigenous and other local knowledge, which include the failure to fully recognise normative claims about whose interests international biodiversity assessments and governance serve [44,45]. The political negotiation of multiple sources of environmental knowledge with multiple decision-making settings, as in REDD+, represents the most complex case for institutionalising the equitable treatment of alternative values regarding how things should be and should be done [46].

Within climate and forest governance, key norms that reflect the three dimensions of environmental justice include respect for the knowledge and rights of local communities and Indigenous Peoples (covering recognition), principles related to full and effective participation and free, prior and informed consent (related to procedure), and norms around equitable benefit sharing (related to distribution) [54-56]. However, power relations guiding policy processes determine that discourses emphasising market-based ecological modernisation as solutions to complex social-ecological problems tend to dominate, such that questions of human rights and respect for the values and practices of cultural minorities remain lower down the hierarchy of norms [57,58]. Market-oriented approaches to environmental (and social) problems can include attention to recognition issues, but have been evidenced to privilege ideals of economic efficiency while alternative values, experiences, and potential forms of governance based on those values are overlooked, subordinated or diluted such that outcomes and modes of governance fall short of the type of justice sought by many local communities worldwide [6,7]. Issues of gender, claims of indigeneity and rights over land and forest resources tend to be subordinated to or form part of broader distributive framings relating to, for example, capacity-building funds rather than being fully debated as separate issues $[59,60]$. Technocratic arguments and approaches to delivering equity through fulfilling safeguard principles tend to overshadow attempts to make global forest governance more inclusive, and the knowledge, values and practices of marginal groups remain unrealised [61-64]. Accordingly, social safeguards associated with climate-related governance represent weak interpretations of recognition-based norms, representing a "do no harm" principle rather than facilitating specific debate about the nuances and different perspectives on these disaggregated impacts and how to promote progressive realisation of human rights [65], and may fail to address injustice in practice [66]. Rather than addressing a range of costs and benefits linked to local values and practices, including loss of cultural and place attachments, distribution issues themselves tend to be reduced to technical exercises for distribution of monetary benefits [67]. These distribution-centric and technocratic approaches to delivering justice also permeate downwards to national-level policy debates through the influence of international donors [54,68], as evidenced through analyses of safeguard approaches in numerous countries developing REDD+ structures, including Indonesia, Mexico, Peru, Tanzania, Vietnam [69] and the Democratic Republic of Congo [70].

Some authors suggest that procedural injustices remain a major failing in global environmental politics because many views are inadequately represented, creating a "democracy gap" [71], 
and despite establishment of some multilevel governance structures which involve civil society organisations in national committees and working groups, their influence over policy direction is seen to be minimal, particularly in the case of cultural minorities [59]. For REDD+ these factors have contributed to the weak implementation of aspects such as free, prior and informed consent of local communities [72], and loss of access, resources and reduced material wellbeing experienced by forest-adjacent communities as a result of implemented projects, despite the existence of social safeguards [73,74]. Global climate and forest policy processes are therefore criticised for their failure to represent the various injustices faced by Indigenous Peoples and local communities, smallholders, women, the poor and those living in vulnerable locations [75-77].

\section{Research Design and Methods}

\subsection{Methodology}

Nepal and Uganda form illustrative case studies for exploring the mobilisation of justice claims among rural, forest-adjacent communities. Both have high levels of rural poverty and livelihood dependence on natural resources, which are particularly acute among minority social and ethnic groups. Dalits and indigenous people together make up approximately half of Nepal's population and their participation in policy, and impacts of policy upon them, are key issues in land and forest governance [78]. Nepal's forest sector implemented community-based forest management in the late 1970 s with $20 \%$ of forests now under such governance schemes [25]. In contrast, in Uganda forest governance comes under state control to a large extent but with extensive customary tenure prevailing, leading to sometimes overlapping management regimes [79]. There are several marginalised social or ethnic groups inhabiting Uganda's forests or land adjacent to them, including the Batwa and Benet, who have suffered severe impacts of forest conservation and whose distinct cultural values and practices justify specific attention within the REDD+ process [80]. Civil society is active in both countries but freedom of expression is constrained or unequal between social groups [81,82]. Nepal has faced long-term political instability, including a ten-year civil war (1996-2006) and frequent changes of government since becoming a multi-party democracy in 1990, whereas Uganda has remained under the leadership of Yoweri Museveni since 1986. Both countries have participated in REDD+ readiness activities since 2009 and are progressing towards implementation.

Our methodology focused on the perceptions of a range of intermediaries, regarding which and whose claims they seek to mobilise, the strategies they pursue, various forums they engage in, other norms they encounter and barriers or opportunities they experience to facilitate norm travel and achievement of various social and environmental aims. Through attention to which and whose norms are prioritised or disregarded in various policy processes or forums, and through what particular institutional arrangements and exercises of influence by specific actors, this form of inquiry provides important insights into power relations in each of our case studies. This approach does not critically assess the extent to which intermediaries effectively represent specific social groups or act in their own strategic interests. Our work's focus is on providing robust insights into actions and interactions to promote norm travel, reactions to perceived barriers and opportunities and claims regarding influence. Semi-structured interviews, each lasting one to two hours (see Supplementary Information for interview guide), were held with 16 intermediaries from Nepal and 16 from Uganda, who were sampled to include varied types of organisations with diverse objectives operating at a variety of scales. Participants primarily represented civil society organisations, but also included state officials, journalists and private sector actors, operating at various levels from local scale community work and mobilisations to national and international networks and policy forums (Table 1). Not one of the 32 intermediaries functioned solely at local, national or international levels, and most worked at all three. For example, even local government officials had attended international United Nations Framework Convention on Climate Change (UNFCCC) conferences. Furthermore, both social and environmental objectives guided the climate-related forestry work of all 32 participants. All interviews 
were conducted by the authors, 26 during 2016, while six interviews were held with subnational intermediaries in Uganda in 2014.

Six interviews in each country were held at local level with intermediaries working in areas adjacent to forests where strict protection for biodiversity conservation has adversely impacted some local communities' resource access, land tenure security and place attachments: around Mount Elgon National Park in Eastern Uganda and Chitwan National Park in Southern Nepal. Again, intermediaries were selected to represent a diversity of organisations and perspectives on forest governance and associated social issues. Around both Mount Elgon and Chitwan National Parks, impacts have been particularly acute for Indigenous Peoples or cultural minorities inhabiting those areas, affecting access to ancestral lands, resources and cultural practices associated with their identities. Whilst these may appear to be extreme examples, similar concerns are evident around forest governance in other parts of Nepal and Uganda, as well as in many other countries [25,83-86]. At Mount Elgon, carbon-based forest governance has been established, initially through The Uganda Wildlife Authority-Forests Absorbing Carbon Emissions (UWA-FACE) project from 1992 and more recently through the Mt. Elgon Regional Eco-System Conservation Programme (MERECP). For the site around Chitwan, REDD+ projects are in the planning stage, though pilot studies have been conducted within the same district [87]. The remaining ten semi-structured interviews in each country were conducted with intermediaries based in the capital cities, Kathmandu and Kampala. Participants were selected to represent a diversity of actors seeking to advance both environmental management and social outcomes of the rural population, and with potential to mobilise and advance justice-related norms based on recognition of local values and practices. The intermediaries participating in this study represented stakeholders in a variety of policy sectors, though all had some involvement in climate-related forest governance and the majority had been directly engaged in formal REDD+ policy processes.

Semi-structured interviews were flexible and exploratory, expanding across a range of topics. At the minimum, interviews sought to elicit perceptions of participants on specific themes in line with the conceptual framework (Figure 1): the intermediaries' priorities in their work; the justice concerns they seek to mobilise, and for which people; the actions and interactions they undertake in different forums to mobilise those concerns and influence different actors and policy debates; any barriers faced in doing so and responses to them; any successes enjoyed and factors enabling them; their perceptions of REDD+ and climate policy processes at different levels of governance, norms within them and level of engagement (see Supplementary Information). Interviews were all conducted in English with answers noted as fully as possible. Transcripts were coded thematically in accordance with the concepts described above and analysed inductively using NVIVO 10 [88].

\subsection{Case Study Sites}

Mount Elgon National Park lies on the border between Uganda and Kenya. The Ugandan side of the National Park is governed by the Uganda Wildlife Authority and covers more than $1000 \mathrm{~km}^{2}$. Due to the fertile volcanic soils and favourable climate for growing crops, the area is one of the most densely populated rural areas in the country. An exclusionary protected area was first established by the British in the early twentieth century, but periods of deforestation, conversion to agriculture and settlement occurred post-independence, in the mid-1970s and again in the early 1980s [89]. The area was declared a National Park in 1993 followed by mass evictions without compensation of potentially more than 100,000 people [90]. This has led to ongoing conflicts and legal proceedings between local communities and authorities, particularly the Uganda Wildlife Authority, over park boundaries, land tenure and human rights violations. These have been particularly acute among the Bagisu and Sabiny ethnic groups, including the Benet, who claim ancestral connections to specific lands around Mount Elgon [91]. Issues were exacerbated through a carbon forestry scheme established in 1992, the Uganda Wildlife Authority-Forests Absorbing Carbon Emissions (UWA-FACE) project, which aimed to reforest 25,000 hectares of degraded land within the newly-established park boundaries. 
Influenced by widely-publicised human rights violations by UWA staff, the project ceased formal operation in 2002, though many ongoing tenure disputes remain unresolved [92,93].

In southern Nepal the establishment of Chitwan National Park in 1973 and demarcation of boundaries resulted in large-scale relocation of the rural population residing inside the park. Boundaries and governance have been intermittently renegotiated with further relocation, including instances of compensated resettlement. Many of those living inside the park were indigenous Tharu, and their gradual relocation, with many being moved to New Padampur with very limited influence over decisions made, has had profound economic, social and cultural impacts, including separation from their ancestral lands and spiritual homes [94]. While more powerful villagers with ample resources were able to gain considerable compensation helping them to adapt to a new environment, away from their cultural practices around riverine resources and wetland farming, many others failed to gain land or adapt their livelihoods to the new surroundings [95].

\section{Results}

\subsection{Prominence of Recognition Issues for Local Communities}

The interviews with intermediaries provided strong evidence that recognition-based concerns of local communities are viewed as important factors to take account of in designing forest governance programmes. In Uganda it is widely acknowledged, as one intermediary put it, that "customary land tenure dominates across this country." This emphasises the prevalence of local values and practices and the importance of related norms being adequately represented in national and international policy. Programmes devised externally by influential international actors are therefore viewed as possible threats to this tenure system. For example, as another intermediary described,

"the World Bank is about competitiveness and enterprise. They are looking for economic growth. That happens through agricultural projects, dams, roads, and that can escalate land conflicts."

Forest conservation in Uganda has been characterised by the imposition of strict protection, which has resulted in severe impacts for local communities and Indigenous Peoples in many areas, including failure to recognise customary tenure and access rights to resources important for traditional practices and livelihoods, with rights being violated through evictions and physical abuse. As a human rights activist operating around the Mount Elgon National Park described:

"Members of these communities claimed that this was their ancestral land, they had the rights to access the land and their ancestors are buried there and they had their homes in that place. After the government gazetted the park, they started to carry out evictions without warning. These were totally violent evictions in which they burned houses, and made human rights violations like rape. They killed around 100 men, women and children and people lost animals and property at that time."

In Nepal, land tenure was also a recognition issue considered of primary importance. Although community management of forests had a long history across the country, rights over land and customary tenure were poorly recognised by the state. Civil society representative, Nepal:

"Rights are held by the government and the system is not able to work for the people. If we want to overcome all the challenges and make sustainable natural resource and forest management we need to change the existing tenurial structure, we need tenure reform ... That's why we are asking for clear tenure on a communal basis."

Intermediaries in Nepal acknowledged that recognition-based injustices, similar in nature to those at Mount Elgon, had occurred both around Chitwan National Park and in relation to forest conservation across the country. Some highlighted the case of the Tharu around Chitwan, who had initially been forcibly evicted from the park, and later many were resettled, after very limited participation in decision-making, in areas which could not provide land and resources suited to their 
cultural practices of river-based livelihoods and agricultural practices. Those entering protected areas to try to access such resources risked being beaten or raped by armed forces. Examples of similar issues relating to non-recognition of values, customary tenure and traditional practices for indigenous groups (who officially make up 37\% of the national population) and for Dalits, particularly women, were provided by intermediaries for protected areas across Nepal. As stated by a civil society representative in Nepal:

"Women are facing violence by armies. In Chitwan alone almost 300 children have been born through gender-based violence."

\subsection{Intermediaries Supporting Distribution and 'Do No Harm' as Paths to Sustainability}

Despite the intermediaries' awareness of recognition issues as relevant to climate-related forest governance, many of those interviewed did not mobilise recognition issues in their work. Half of the 32 interviewees-nine in Uganda and seven in Nepal—paid little regard to issues of tenure or cultural identities and practices. Although all 16 pursue social objectives in their work, they commonly emphasise norms about distribution, particularly based around economic solutions to promote sustainability and address social problems, whilst downplaying issues of recognition. Local government officer, Uganda:

"If people remain in poverty, they will remain in rural areas ... We are arguing for the government to come up with a big project for people nearby parks to urbanise and move out of poverty."

This group of intermediaries tend to accept the dominant norm complex in climate-related forest governance, which treats the recognition of affected forest communities as of marginal relevance. Some view local practices to be in conflict with ecological sustainability rather than positively linked or part of potentially sustainable solutions; that local communities are responsible for creating conflicts through unreasonable claims to land, which are not recognised by, or valid in, law: these intermediaries therefore actively favour policy options which would work against recognition claims impeding the travel of recognition norms to national and international institutions on forest governance.

Journalist, Uganda:

"People need to be educated, FACE (carbon forestry project at Mount Elgon) did the right thing by sticking to the 1993 park boundary, but people didn't like that. I haven't really seen any mobilization: people just respond and react. People might sometimes cause conflict, then UWA responds forcibly."

In line with their focus on more tangible or objective social norms and a 'do no harm' principle, some of those norm-takers do seek to mobilise local concerns when objective, physical harm is being imposed on local communities and clear human rights violations have been committed.

Local government officer at Mount Elgon, Uganda:

"UWA was behaving like an organisation that doesn't care about people's lives. They were just shooting people for taking firewood, and raping women with firewood who had strayed into the national park. We had to bring the head of police in, the inspector general of police. When UWA were raping women and dehumanising men, and cutting crops when they were about to mature-we think this is really inhuman."

From their perspectives, those norm-takers perceived that social safeguards within REDD+ and climate governance are adequate to address relevant social concerns, and focused on distribution of material benefits to minority groups or to promote alternative livelihoods to reduce their forest uses as primary mechanisms for providing more sustainable and just outcomes.

Government official, Nepal:

"If the money amount is big and they've reduced deforestation, then we can distribute some to households. The main guiding principle behind benefit sharing would be livelihood diversification to 
reduce dependency on the forests... 2nd is the social safeguards for marginalised groups. We have to think about that as well so a percentage (of monetary benefit) will go for their welfare, also technical stuff for training them too."

\subsection{Norm Entrepreneurs' Efforts to Mobilise Recognition-Based Norms in Support of Sustainability}

The remaining half of the 32 intermediaries interviewed (nine in Nepal and seven in Uganda) sought to mobilise recognition-based claims of local communities to varying extents, emphasising recognition of local values and practices as a pathway to enhanced social outcomes and ecological sustainability. From their perspective, enhanced recognition can reduce environmental conflicts that undermine sustainable practices and foster greater legitimacy, trust and support for sustainable development programmes or regulations. As one norm-entrepreneur in Nepal expressed:

"There are so many customary practices to manage natural resources sustainably, but the trust (of authorities) is gone, there is none of it there."

Similarly, in Uganda a local representative of a community evicted from Mount Elgon National Park elaborated:

"When living on our piece of land, we kept the environment very well, we kept our trees. But when UWA take over and there they are now doing charcoal burning and sawing — the park may not be forested in ten years. But formerly, we were caring for trees. Now there is no good relationship between community and UWA and there is no security for our environment."

Furthermore, this group of intermediaries suggested that recognition of local natural resource management practices can proactively empower local communities to mobilise against unsustainable initiatives such as removing primary forests or damaging watercourses for short-term extractive gains, proposals often supported by local and national government agencies. A Ugandan civil society actor described:

"Especially where the ownership of the land is customary, those people have no documentation of their entitlements, so we work mostly in that area at present... Speculators are evicting people with minimal compensation ... We gathered together two groups ... to give the people there greater strength. They know their rights and can push away investors... The challenge is to represent the value of the forest."

The greatest examples of normative and transformative progress towards enhanced recognition for local communities, particularly for cultural minorities in both countries, were made through several simultaneous tactics which facilitated justice-related norm travel between local communities, national advocacy coalitions and international donors. Described and exemplified below, this mobilisation pathway was followed by four civil society interviewees representing either human rights or land rights in Uganda, and in Nepal for seven intermediaries promoting Dalit rights, tenure rights related to community forestry, Indigenous Peoples, gender equity and transformation of land conflicts.

Initially, intermediaries worked at the grass roots level to support the establishment of local associations among those with common recognition claims and promote awareness of rights and to potentially pool knowledge and resources among them.

Civil society representative for land rights, Uganda:

"We advocate for fair land laws and policies. We are strong at the national level, we influence policy effectively but most of our success is at grass roots level. Given the very weak implementation of laws, the abusive policies which we face, we have to stand by people at the local level. Where they are particularly vulnerable we stand by them ... We formed communal land associations on clan grounds ... We are now trying to champion this across the country as a way forward." 
In tandem with building local groups, this particular justice broker, among others, then sought to raise awareness, using various media channels and through building of coalitions of interest, to gain the involvement of powerful external actors. Those actors included international donors and multilateral organisations, who supported collective action based on norms within their organisations or those promoted in democratic, developed nations, for example to seek legal redress for human rights violations, while providing some protection against authoritarian reaction to those local groups. For example, one interviewee described how he and other human rights activists around Mount Elgon used radio and internet to publicise human rights violations by the Uganda Wildlife Authority, culminating in support from international non-governmental organisations, production of a powerful documentary which was widely disseminated and led to involvement of important donors to Uganda, the European Union and World Bank, who applied pressure to the Ugandan government ('Mount Elgon Violations', Uganda Human Rights Network, Published 2011 by World Resources Institute [96]).

Human rights activist, Uganda:

"When donors come, they put certain pressures on. The documentary was helpful. When donor money is implicated in human rights violations, they cannot accept that-World Bank money cannot be implicated in human rights violations. So we lobby them."

This international pressure led to very direct norm travel, through a programme conducted by Uganda's Human Rights Network to train UWA staff, from rangers to senior staff, in human rights approaches.

A third strand of this overall strategy was to act as part of, and advocate for change through, multiscale networks focused on specific minority groups or recognition issues with international umbrella organisations, forums and influence. Those umbrella organisations, or in some cases, expert individuals, often provide training and advice on how to successfully advocate for change. For example, an interviewee representing a civil society organisation in Nepal gained funding and training from charitable bodies, academics and practitioners focused on mediation and conflict transformation. Through internationally-led and funded training with government officials and marketing campaigns including social media this has resulted in changed approaches to more than 75 land tenure-based conflicts across the country, often involving longstanding issues of non-recognition of the values and practices of cultural minorities. In Uganda, a representative of a land rights organisation reported that, through the International Land Coalition in Rome, such a strategy is leading to the widespread piloting of communal land agreements, funded by the World Bank, after almost 20 years of legal provision remaining dormant, unimplemented by the government. That strategy was also reported to have helped prevent a government plan to reform the constitution to make acquisition of land easier for large-scale private investment projects.

This strategy was, however, not successful for all intermediaries pursuing enhanced recognition. In some instances, normative barriers were perceived to be too great, most evidently in the case of Dalit rights, for whom mobilisation appeared to be normatively restricted at all levels of governance and in all forums. Here the enduring structure of caste hierarchy points to constraints on the cross-scalar movement of justice-as-recognition norms, arising from a particular political economy context.

As one civil society representative for Dalit rights in forest governance in Nepal stated:

"Dalits are not recognised, there are no institutions to represent them... Nepal does suggest in the UN conventions to get Dalits recognised, but India always blocks that, and there are 200 million plus Dalit in India ... Our political network is very weak ... even individual consultants have more power than us. The media just feel sorrow but they can't really support us. You know everyone knows IPs (Indigenous Peoples) but no one in the world knows Dalit." 
3.4. Limitations in the REDD+ (National and International) and UNFCCC Climate Forums as Perceived by Justice Brokers

Ostensibly, the set of strategies described above served to bypass mainstream policy fields such as climate change, REDD+, biodiversity conservation, poverty reduction and so on at the national level. Although norm entrepreneurs still maintained some involvement in these policy fields, these were perceived to be more restricted spaces for progressive norm travel and transformative change.

Civil society representative, Uganda:

"People are not challenging that hierarchy, the knowledge barriers they impose. Other people who would do something get lost in that process. At meetings people get very angry at how they are run. So we need the capacity for people to challenge that at every level, the international, national ... It's become populated with people who won't rattle the cage. It's unimplementable."

Civil society representative, Nepal:

"There are social criteria in implementation, a certain percentage of money for women etc. But the question is really if you take that formal approach, it is not just a question of distribution but one of marginalisation."

Many justified their involvement in REDD+ policy or on the national working group not through support for the programme or the potential for enhanced recognition of tenure, values and rights, but because of the need to maintain a presence to ensure sufficient protection against further injustice through deterioration of rights or misrecognition.

Civil society representative, Nepal:

"The remaining rights and livelihoods Indigenous Peoples have, they are already deprived, so there is chance of their titles being sold, whole areas can be restricted to people. So instead of making these claims about REDD, we try instead to affect the discourse to ensure that those Indigenous Peoples' claims are at least there and recorded, so we can be sure that their tenure will not be diminished even further."

Efforts to lobby government and donors through these processes were therefore viewed as less effective strategies, and occasionally resulted in subsequent exclusion from them, as reported by four different interviewees. For example, an interviewee acting as a proponent of gender equity in Nepal suggested that attempts to raise gender equity as a topic had led to exclusion from formal REDD+ policy processes.

"Like with REDD, I don't get invited to the working group meetings anymore. I don't know why.

But it is important to get knowledge heard in the process. It's hard to get gender and inclusion in."

Subsequently that person opted to devote more resources to forums associated with the Sustainable Development Goals rather than climate change or REDD+ due to greater perceived inclusion and opportunity for influence.

Most norm entrepreneurs also avoided climate policy arenas at the international level, perceiving them as constrained forums for debating recognition-based norms. Mainstream policy is instead heavily focused on inequality between nations and distributional mechanisms to provide technical capacity to implement market-based solutions. As an exception, those supporting indigenous groups in Nepal had gained status and (despite continuing instances of exclusion from some discussions) increasing participation at United Nations Framework Convention on Climate Change policy forums and sought to use those to gain meaningful recognition of their values, tenure systems and practices in international policy, through which to indirectly influence recognition or at least the level and quality of political participation at national level, for instance:

"The Indigenous Peoples movement has a very long history and basis to be recognised as a separate constituency under UNFCCC ... There has also been elaboration of collective human rights. That recommendation allows us to push issues forward." 
Yet, even representatives of indigenous organisations felt their participation in such state-centred international forums was highly constrained, stating that they relied on non-indigenous champions and informal, opportunistic associations with political leaders to achieve meaningful moments of political influence.

\section{Discussion}

Global forest governance is proliferating with considerable financial and institutional resources being directed towards policy processes to inform projects targeting ambitious ecological and social goals. Those processes involve a wide range of intermediary actors, or justice brokers, across civil society, state and private sector. But although presenting potential forums to address the persistent justice concerns of local communities and cultural minorities, justice-related norms tend to be reduced to technical monitoring exercises geared towards doing no harm rather than progressively recognising diverse identities, values, practices, vulnerabilities and potential contributions to sustainable natural resource management [7]. Recognition-based concerns are essentially washed out of equity framings carried forward in policy discussions, such that the form of equity discussed in formal policy processes carries a different meaning to the forms of justice sought by local communities [69]. Yet, as our case studies show, REDD+ or forest and climate governance programmes are implemented not in simple socio-political contexts but complex situations of high social diversity, power inequalities and longstanding recognition-based struggles, where lack of local legitimacy and trust of authorities is likely to threaten their ecological effectiveness. These conditions indicate an imperative for the 'weaving' of indigenous and local understandings of ecosystem services and governance norms into mainstream policy processes [44], though such boundary work to bridge normative differences is absent in REDD+, being precluded because the institutions designing and leading the processes struggle to accommodate justice-related recognition norms in social safeguarding discourses and practices. REDD+, as debated in policy forums in Uganda and Nepal, offers weak opportunities for upward travel of local norms and associated advances in social development because of the absence of boundary institutions as forums to negotiate these diverse perspectives. Therefore, the way equity is framed is inadequate to address injustice, and a justice gap between local perspectives and policy processes persists.

Although the constrained political space in climate governance has been detailed previously, at international and national levels [8], our analysis of intermediary perspectives and actions in Nepal and Uganda provides enhanced theoretical and practical understanding of the politics of scale and barriers to reconciliation of contrasting justice-related norms. It supports a broad conception of intermediaries (negotiating over the provision and effects of ecosystem services) as creating, and operating in, both formal and informal networks, depending on perceived opportunities for influence [38]. Advancing such understanding is important to inform sustainability science, not least "because how these intractable issues of justice are dealt with (or not) will be a crucial factor in determining the effectiveness of the emerging climate regime," [60].

It may appear, from policy discussions underway, that REDD+ processes have gained widespread participation from civil society, state and private sector stakeholders. However, our in-depth analysis of governance processes and power relations reveals that intermediaries involved in REDD+ are polarised between those who give precedence to recognition-based issues and those who deprioritise them in favour of ecological goals or more simplistic framings of equity. This brings into question claims of inclusivity and effective participation in national-scale climate policy processes. Our findings uncover how intermediaries seeking to mobilise recognition claims of local communities do not target climate policy processes, including REDD+, as progressive forums for transformative change and those who maintain involvement do so simply to avert further erosion of rights and cultural recognition. Several evade REDD+ and climate policy processes altogether, in favour of alternative forums and policy arenas offering more opportunities for progressive norm travel, a tactic described in other studies on environmental policy negotiations [49]. The prioritisation and pursuit of recognition-centred 
justice claims by half of the intermediaries in this study, and their dissatisfaction with REDD+ and climate policy debates, focused on issues of material distribution or simplistic interpretations of procedural justice, supports the argument made by prominent theorists that attempts to realise just, emancipatory outcomes, or even simply to gain legitimacy among affected people, will fail if they disregard recognition of diverse values, identities and practices [97,98]. Attention to recognition as a central pillar of just or equitable environmental conservation policy has been severely lacking [22]. Our analysis shows that neglected aspects of recognition include customary and communal tenure systems over land and resources and group-specific place attachments. These themes, and barriers to upward travel of norms related to local tenurial institutions, were consistent for both Uganda and Nepal, despite their different social and political contexts.

Our findings raise questions as to why opportunities to advance land tenure, human rights and cultural respect (and their potential contribution to environmental sustainability) do not avail in climate governance. The balance of institutional power leans towards economic and ecological objectives, precluding not only consideration of aspects of local community wellbeing and experiences, but of alternative forms of governance or debates about them, and forecloses the potential for empowering transformation, including rebuilding of trust with local communities, support for customary practices and enhanced local stewardship [99]. Programmes formed as part of global climate governance are consequently perceived as threats rather than opportunities by vulnerable and marginal groups and civil society working on their behalf. Yet climate governance consists of numerous sustainable and human development programmes, such that the evident suppression of contemporary (and in other governance regimes, powerful) norms on human rights, indigenous knowledge and land tenure systems is counterproductive for REDD+ implementation. To realise the possibility for both social and environmental gains for vulnerable and marginal groups and overcome persistent issues of mistrust which impede them, progressive norms based on recognising diverse knowledge systems, land and resource rights, and place-based identities must be made central to governance processes for climate and sustainability $[15,100]$. Practically, this must include continuous participation and representation of local communities and specific social groups, with meaningful opportunities for them to influence policy, monitoring and programme design, not only through representation in national-level processes. More effective coalition-building, among civil society groups with aligned normative stances and objectives, and strategic efforts across local, national and international scales, could foster greater attention to recognition issues in REDD+, and may yet emerge in numerous countries if negative social impacts continue to come to light.

Attention to the politics of norm negotiation and 'travel' have an important role in empirical studies of justice and to inform critical sustainability sciences. Consideration of processes of policy negotiation and norm travel as multidirectional, multidimensional and multiscalar across a diversity of forums facilitates greater understanding of the barriers and enabling factors for appropriate negotiation to inform policy implementation approaches that may be considered legitimate on the ground. Local-level norms are unlikely to be visible in policy and may be underrepresented in discourses, such that the perspectives of actors at various scales require elicitation, from local communities to justice brokers involved in mobilising social movements [19,37]. The political dynamics involved in norm negotiation may serve to reproduce and perpetuate injustice with important social and environmental consequences. In certain cases, the interactions leading to mobilisation and uptake of local norms may help to overcome seemingly entrenched injustices, and the factors enabling such advances can provide key lessons to inform emancipatory initiatives and shape transformative pathways of change.

\section{Conclusions}

Justice brokers in forest governance face complex political and institutional contexts in which to promote enhanced recognition of values and practices for forest-adjacent communities. Our findings from Uganda and Nepal illustrate that those who manage to do so can truly be considered to have exhibited norm entrepreneurship. Studies have described aspects of the political maneuvering and 
negotiation of power undertaken by intermediaries [43], yet the complexity of pathways taken to overcome political barriers and further recognition of justice have seldom been elaborated. Norm entrepreneurship in our study entailed not just a single tactic or opportunistic event, but a cumulative strategic web involving multiple actions and interactions across diverse forums at various scales. Each of the recognition norm entrepreneurs identified in this study engaged in manifold tactics as part of their strategy, working at local, subnational, national and international levels, across different networks, types of media, via capacity-building support networks and found pathways to reach powerful global organisations considered potentially responsive to their normative cases. Climate policy processes, including REDD+, were perceived by many intermediaries to be restricted political spaces where progressive debate of recognition-based issues was absent or unproductive and local practices were commonly framed as threats to sustainability rather than potential solutions. As a result, the civil society actors seeking to advance recognition avoided participating in them or maintained involvement only to avoid a perceived further erosion of rights. By engaging in a combination of grass roots activism, building national coalitions of interest, undertaking advocacy campaigns and through embedding themselves within supportive international networks outside of climate policy processes, civil society organisations in Nepal and Uganda have made substantial gains for local communities and effected normative change on human rights and the recognition of customary tenure, even in the face of challenging political environments. Only through this strategic web of multiple interrelated tactics were they able to create various conditions for and build momentum to facilitate travel of recognition-based norms, working to close the justice gap between local perceptions and global sustainability governance.

Supplementary Materials: The following are available online at http:/ / www.mdpi.com/2071-1050/10/6/1726/ s1, Intermediary interview guide.

Author Contributions: All authors conceived and designed the study. N.M.D., H.D., J.A.F. and D.M.M. performed the interviews. Dawson analysed the data and wrote the paper with contributions from all co-authors.

Acknowledgments: We thank Thomas Sikor who initiated and inspired this project and the participants whose time and openness made this study possible. The work was funded by the UK Department for International Development (DFID) and the Economic and Social Research Council (ESRC) Development Frontiers Grant Number ES/N005740/1.

Conflicts of Interest: The authors declare no conflict of interest. The founding sponsors had no role in the design of the study; in the collection, analyses, or interpretation of data; in the writing of the manuscript, and in the decision to publish the results.

\section{References}

1. Scholte, J.A. Building Global Democracy?: Civil Society and Accountable Global Governance; Cambridge University Press: Cambridge, UK, 2011.

2. Schlosberg, D.; Collins, L.B. From environmental to climate justice: Climate change and the discourse of environmental justice. Wiley Interdiscip. Rev. Clim. Chang. 2014, 5, 359-374. [CrossRef]

3. Suiseeya, K.R.M. The Justice Gap in Global Forest Governance; Duke University: Durham, NC, USA, 2014.

4. Klinsky, S.; Winkler, H. Equity, sustainable development and climate policy. Clim. Policy 2014, 14, 1-7. [CrossRef]

5. Somorin, O.A.; Visseren-Hamakers, I.J.; Arts, B.; Sonwa, D.J.; Tiani, A.-M. REDD+ policy strategy in cameroon: Actors, institutions and governance. Environ. Sci. Policy 2014, 35, 87-97. [CrossRef]

6. Okereke, C.; Dooley, K. Principles of justice in proposals and policy approaches to avoided deforestation: Towards a post-kyoto climate agreement. Glob. Environ. Chang. 2010, 20, 82-95. [CrossRef]

7. Bäckstrand, K.; Lövbrand, E. The road to paris: Contending climate governance discourses in the post-copenhagen era. J. Environ. Policy Plan. 2016, 1-19. [CrossRef]

8. Suiseeya, K.R.M. Contesting justice in global forest governance: The promises and pitfalls of REDD+. Conserv. Soc. 2017, 15, 189. [CrossRef]

9. Blais-McPherson, M.; Rudiak-Gould, P. Strengthening inter-disciplinary and inter-ideological collaboration on redd: A cultural theory approach. Glob. Environ. Chang. 2017, 42, 13-23. [CrossRef] 
10. Marino, E.; Ribot, J. Special issue introduction: Adding insult to injury: Climate change and the inequities of climate intervention. Glob. Environ. Chang. 2012, 22, 323-328. [CrossRef]

11. Mariki, S.B.; Svarstad, H.; Benjaminsen, T.A. Elephants over the cliff: Explaining wildlife killings in tanzania. Land Use Policy 2015, 44, 19-30. [CrossRef]

12. Dawson, N.; Grogan, K.; Martin, A.; Mertz, O.; Pasgaard, M.; Rasmussen, L.V. Environmental justice research shows the importance of social feedbacks in ecosystem service trade-offs. Ecol. Soc. 2017, 22, 12. [CrossRef]

13. Kates, R.W.; Clark, W.C.; Corell, R.; Hall, J.M.; Jaeger, C.C.; Lowe, I.; McCarthy, J.J.; Schellnhuber, H.J.; Bolin, B.; Dickson, N.M. Sustainability science. Science 2001, 292, 641-642. [CrossRef] [PubMed]

14. Agyeman, J.; Bullard, R.D.; Evans, B. Exploring the nexus: Bringing together sustainability, environmental justice and equity. Space Polity 2002, 6, 77-90. [CrossRef]

15. Rist, S.; Dahdouh-Guebas, F. Ethnosciences-A step towards the integration of scientific and indigenous forms of knowledge in the management of natural resources for the future. Environ. Dev. Sustain. 2006, 8 , 467-493. [CrossRef]

16. Adger, W.N.; Brown, K.; Fairbrass, J.; Jordan, A.; Paavola, J.; Rosendo, S.; Seyfang, G. Governance for sustainability: Towards a 'thick' analysis of environmental decisionmaking. Environ. Plan. A 2003, 35, 1095-1110. [CrossRef]

17. Biermann, F. ‘Earth system governance'as a crosscutting theme of global change research. Glob. Environ. Chang. 2007, 17, 326-337. [CrossRef]

18. Frey, U.J. A synthesis of key factors for sustainability in social-ecological systems. Sustain. Sci. 2017, 12, 507-519. [CrossRef]

19. Jacobi, J.; Mathez-Stiefel, S.-L.; Gambon, H.; Rist, S.; Altieri, M. Whose knowledge, whose development? Use and role of local and external knowledge in agroforestry projects in bolivia. Environ. Manag. 2017, 59, 464-476. [CrossRef] [PubMed]

20. Klinsky, S.; Golub, A. Justice and sustainability. In Sustainability Science; Springer: Berlin, Germany, 2016; pp. 161-173.

21. Biermann, F.; Kanie, N.; Kim, R.E. Global governance by goal-setting: The novel approach of the un sustainable development goals. Curr. Opin. Environ. Sustain. 2017, 26, 26-31. [CrossRef]

22. Martin, A.; Coolsaet, B.; Corbera, E.; Dawson, N.M.; Fraser, J.A.; Lehman, I.; Rodriguez, I. Justice and conservation: The need to incorporate recognition. Biol. Conserv. 2016, 197, 254-261. [CrossRef]

23. De Jonge, B. What is fair and equitable benefit-sharing? J. Agric. Environ. Ethics 2011, 24, 127-146. [CrossRef]

24. Anderson, J.; Honneth, A. Autonomy, vulnerability, recognition, and justice. In Autonomy and the Challenges to Liberalism: New Essays; Cambridge University Press: Cambridge, UK, 2005; pp. 127-149.

25. Larson, A.M.; Barry, D.; Dahal, G.R.; Colfer, C.J.P. Forests for People: Community Rights and Forest Tenure Reform; Earthscan: London, UK, 2010; 263p.

26. Walker, G. Environmental Justice: Concepts, Evidence and Politics; Routledge: Abingdon, UK, 2012.

27. Honneth, A. The Struggle for Recognition: The Moral Grammar of Social Conflicts; MIT Press: Cambridge, MA, USA, 1996.

28. Hegel, G.W.F. The Philosophy of Right; Hackett Publishing: Indianapolis, IN, USA, 2015.

29. Finnemore, M.; Sikkink, K. International norm dynamics and political change. Int. Organ. 1998, 52, 887-917. [CrossRef]

30. Mukhtarov, F. Rethinking the travel of ideas: Policy translation in the water sector. Policy Polit. 2014, 42, 71-88. [CrossRef]

31. Thompson, M.C.; Baruah, M.; Carr, E.R. Seeing REDD+ as a project of environmental governance. Environ. Sci. Policy 2011, 14, 100-110. [CrossRef]

32. Satyal, P.; Corbera, E.; Dawson, N.; Dhungana, H.; Maskey, G. Representation and participation in formulating Nepal's REDD+ approach. Clim. Policy 2018. [CrossRef]

33. Thomas, D.S.; Twyman, C. Equity and justice in climate change adaptation amongst natural-resource-dependent societies. Glob. Environ. Chang. 2005, 15, 115-124. [CrossRef]

34. Oberlack, C.; Walter, P.L.; Schmerbeck, J.; Tiwari, B. Institutions for sustainable forest governance: Robustness, equity, and cross-level interactions in Mawlyngbna, Meghalaya, India. Int. J. Commons 2015, 9, 670-697. [CrossRef]

35. Acharya, A. How ideas spread: Whose norms matter? Norm localization and institutional change in asian regionalism. Int. Organ. 2004, 58, 239-275. [CrossRef] 
36. Hargreaves, T.; Hielscher, S.; Seyfang, G.; Smith, A. Grassroots innovations in community energy: The role of intermediaries in niche development. Glob. Environ. Chang. 2013, 23, 868-880. [CrossRef]

37. Bäckstrand, K. Civic science for sustainability: Reframing the role of experts, policy-makers and citizens in environmental governance. Glob. Environ. Polit. 2003, 3, 24-41. [CrossRef]

38. Schröter, B.; Matzdorf, B.; Hackenberg, I.; Hauck, J. More than just linking the nodes: Civil society actors as intermediaries in the design and implementation of payments for ecosystem services-the case of a blue carbon project in costa rica. Local Environ. 2018, 23, 1-17. [CrossRef]

39. Routledge, P.; Nativel, C.; Cumbers, A. Entangled logics and grassroots imaginaries of global justice networks. Environ. Polit. 2006, 15, 839-859. [CrossRef]

40. Lebel, L.; Garden, P.; Imamura, M. The politics of scale, position, and place in the governance of water resources in the Mekong region. Ecol. Soc. 2005, 10, 18. [CrossRef]

41. Bickerstaff, K.; Agyeman, J. Assembling justice spaces: The scalar politics of environmental justice in north-east England. Antipode 2009, 41, 781-806. [CrossRef]

42. Gupta, J. ‘Glocal'politics of scale on environmental issues: Climate change, water and forests. Scale-Sensit. Gov. Environ. 2014, 140-156.

43. Sikor, T.; Dhungana, H.; Maskey, G. Justice Brokers, Global Indigenous Rights and Struggles over Hydropower in Nepal; Working Paper 52; Dev. Working Paper Series; The School of International Development, University of East Anglia: Norwich, UK, 2015.

44. Tengö, M.; Hill, R.; Malmer, P.; Raymond, C.M.; Spierenburg, M.; Danielsen, F.; Elmqvist, T.; Folke, C. Weaving knowledge systems in IPBES, CBD and beyond-lessons learned for sustainability. Curr. Opin. Environ. Sustain. 2017, 26, 17-25. [CrossRef]

45. Clark, W.C.; Tomich, T.P.; Van Noordwijk, M.; Guston, D.; Catacutan, D.; Dickson, N.M.; McNie, E. Boundary work for sustainable development: Natural resource management at the consultative group on international agricultural research (CGIAR). Proc. Natl. Acad. Sci. USA 2016, 113, 4615-4622. [CrossRef] [PubMed]

46. Van Noordwijk, M. Integrated natural resource management as pathway to poverty reduction: Innovating practices, institutions and policies. Agric. Syst. 2017. [CrossRef]

47. Agyeman, J. Global environmental justice or le droit au monde? Geoforum 2014, 54, 236-238. [CrossRef]

48. Keck, M.E.; Sikkink, K. Transnational advocacy networks in international and regional politics. Int. Soc. Sci. J. 1999, 51, 89-101. [CrossRef]

49. Witter, R.; Marion Suiseeya, K.R.; Gruby, R.L.; Hitchner, S.; Maclin, E.M.; Bourque, M.; Brosius, J.P. Moments of influence in global environmental governance. Environ. Polit. 2015, 24, 894-912. [CrossRef]

50. Savaresi, A. REDD+ and human rights: Addressing synergies between international regimes. Ecol. Soc. 2013, 18, 5. [CrossRef]

51. Wallbott, L. Indigenous peoples in UN REDD+ negotiations:“Importing power” and lobbying for rights through discursive interplay management. Ecol. Soc. 2014, 19, 21. [CrossRef]

52. Zwingel, S. How do norms travel? Theorizing international women's rights in transnational perspective. Int. Stud. Q. 2012, 56, 115-129. [CrossRef]

53. Schlosberg, D.; Carruthers, D. Indigenous struggles, environmental justice, and community capabilities. Glob. Environ. Polit. 2010, 10, 12-35. [CrossRef]

54. Bastakoti, R.R.; Davidsen, C. Framing REDD+ at national level: Actors and discourse around Nepal's policy debate. Forests 2017, 8, 57. [CrossRef]

55. McDermott, C.L.; Coad, L.; Helfgott, A.; Schroeder, H. Operationalizing social safeguards in REDD+: Actors, interests and ideas. Environ. Sci. Policy 2012, 21, 63-72. [CrossRef]

56. Sikor, T.; Stahl, J.; Enters, T.; Ribot, J.C.; Singh, N.M.; Sunderlin, W.D.; Wollenberg, E. REDD-plus, forest people's rights and nested climate governance. Glob. Environ. Chang. 2010, 20, 423-425. [CrossRef]

57. Stevenson, H.; Dryzek, J.S. The discursive democratisation of global climate governance. Environ. Polit. 2012, 21, 189-210. [CrossRef]

58. Bäckstrand, K.; Lövbrand, E. Research Handbook on Climate Governance; Edward Elgar Publishing: Cheltenham, UK, 2015.

59. Mathur, V.N.; Afionis, S.; Paavola, J.; Dougill, A.J.; Stringer, L.C. Experiences of host communities with carbon market projects: Towards multi-level climate justice. Clim. Policy 2014, 14, 42-62. [CrossRef]

60. Okereke, C.; Coventry, P. Climate justice and the international regime: Before, during, and after Paris. Wiley Interdiscip. Rev. Clim. Chang. 2016, 7, 834-851. [CrossRef] 
61. Gupta, A.; Mason, M. Disclosing or obscuring? The politics of transparency in global climate governance. Curr. Opin. Environ. Sustain. 2016, 18, 82-90. [CrossRef]

62. Roosvall, A.; Tegelberg, M. Framing climate change and indigenous peoples: Intermediaries of urgency, spirituality and de-nationalization. Int. Commun. Gaz. 2013, 75, 392-409. [CrossRef]

63. Schroeder, H.; McDermott, C. Beyond carbon: Enabling justice and equity in REDD+ across levels of governance. Ecol. Soc. 2014, 19, 31. [CrossRef]

64. Beymer-Farris, B.A.; Bassett, T.J. The redd menace: Resurgent protectionism in Tanzania's mangrove forests. Glob. Environ. Chang. 2012, 22, 332-341. [CrossRef]

65. Suiseeya, K.R.M. Transforming justice in REDD+ through a politics of difference approach. Forests 2016, 7, 300. [CrossRef]

66. Poudyal, M.; Ramamonjisoa, B.; Hockley, N.; Rakotonarivo, O.; Gibbons, J.; Mandimbiniaina, R.; Rasoamanana, A.; Jones, J. Can REDD+ social safeguards reach the 'right' people? Lessons from Madagascar. Glob. Environ. Chang.-Hum. Policy Dimens. 2016, 37, 31-42. [CrossRef]

67. Schroeder, D.; Pogge, T. Justice and the convention on biological diversity. Ethics Int. Aff. 2009, 23, $267-280$. [CrossRef]

68. Ravikumar, A.; Larson, A.; Duchelle, A.; Myers, R.; Tovar, J.G. Multilevel governance challenges in transitioning towards a national approach for REDD+: Evidence from 23 subnational REDD+ initiatives. Int. J. Commons 2015, 9, 909-931. [CrossRef]

69. Myers, R.; Larson, A.M.; Ravikumar, A.; Kowler, L.F.; Yang, A.; Trench, T. Messiness of forest governance: How technical approaches suppress politics in REDD+ and conservation projects. Glob. Environ. Chang. 2018. [CrossRef]

70. Pelletier, J.; Horning, N.; Laporte, N.; Samndong, R.A.; Goetz, S. Anticipating social equity impacts in REDD+ policy design: An example from the Democratic Republic of Congo. Land Use Policy 2018, 75, 102-115. [CrossRef]

71. Dodds, F.; Strauss, M.; Strong, M.F. Only One Earth: The Long Road via Rio to Sustainable Development; Routledge: Abingdon, UK, 2012.

72. Arhin, A.A. Safeguards and dangerguards: A framework for unpacking the black box of safeguards for REDD+. For. Policy Econ. 2014, 45, 24-31. [CrossRef]

73. Bayrak, M.M.; Marafa, L.M. Ten years of REDD+: A critical review of the impact of REDD+ on forest-dependent communities. Sustainability 2016, 8, 620. [CrossRef]

74. Suiseeya, K.R.M.; Caplow, S. In pursuit of procedural justice: Lessons from an analysis of 56 forest carbon project designs. Glob. Environ. Chang. 2013, 23, 968-979. [CrossRef]

75. Briant Carant, J. Unheard voices: A critical discourse analysis of the millennium development goals' evolution into the sustainable development goals. Third World Q. 2016, 38, 16-41. [CrossRef]

76. Enns, C.; Bersaglio, B.; Kepe, T. Indigenous voices and the making of the post-2015 development agenda: The recurring tyranny of participation. Third World Q. 2014, 35, 358-375. [CrossRef]

77. Brugnach, M.; Craps, M.; Dewulf, A. Including indigenous peoples in climate change mitigation: Addressing issues of scale, knowledge and power. Clim. Chang. 2017, 140, 19-32. [CrossRef]

78. Paudel, N.S.; Vedeld, P.O. Prospects and challenges of tenure and forest governance reform in the context of REDD+ initiatives in Nepal. For. Policy Econ. 2015, 52, 1-8. [CrossRef]

79. Naughton-Treves, L.; Alix-Garcia, J.; Chapman, C.A. Lessons about parks and poverty from a decade of forest loss and economic growth around Kibale National Park, Uganda. Proc. Natl. Acad. Sci. USA 2011, 108, 13919-13924. [CrossRef] [PubMed]

80. Cavanagh, C. Unready for REDD+? Lessons from Corruption in Ugandan Conservation Areas; Chr. Michelsen Institute: Bergen, Norway, 2012; p. 4.

81. Bhandari, M. Civil society and non-governmental organizations (NGOs) movements in Nepal in terms of social transformation. Pac. J. Sci. Technol. 2014, 15, 177-189.

82. Robinson, M.; Friedman, S. Civil society, democratization, and foreign aid: Civic engagement and public policy in south africa and Uganda. Democratisation 2007, 14, 643-668. [CrossRef]

83. Persha, L.; Fischer, H.; Chhatre, A.; Agrawal, A.; Benson, C. Biodiversity conservation and livelihoods in human-dominated landscapes: Forest commons in South Asia. Biol. Conserv. 2010, 143, 2918-2925. [CrossRef] 
84. Tumusiime, D.M.; Svarstad, H. A local counter-narrative on the conservation of mountain gorillas. Forum Dev. Stud. 2011, 38, 239-265. [CrossRef]

85. Zaninka, P. The impact of (forest) nature conservation on indigenous peoples: The batwa of south-western Uganda: A case study of the mgahinga and bwindi impenetrable forest conservation trust. Case Study 2001, 5, 165-194.

86. Robinson, B.E.; Masuda, Y.J.; Kelly, A.; Holland, M.B.; Bedford, C.; Childress, M.; Fletschner, D.; Game, E.T.; Ginsburg, C.; Hilhorst, T. Incorporating land tenure security into conservation. Conserv. Lett. 2018, 11, e12383. [CrossRef]

87. Marquardt, K.; Pain, A. REDD+, forest transition, agrarian change and ecosystem services in the hills of Nepal. Hum. Ecol. 2016, 44, 229-244. [CrossRef]

88. QSR. Nvivo Qualitative Data Analysis Software Version 10; QSR International PTY Ltd.: Oakville, ON, Canada, 2012.

89. Norgrove, L.; Hulme, D. Confronting conservation at Mount Elgon, Uganda. Dev. Chang. 2006, 37, 1093-1116. [CrossRef]

90. Vangen, C. Evicted in the Name of Nature: The Process of Eviction and Its Impact on Local Rural Livelihoods in Mount Elgon, Uganda. Master's Thesis, Norwegian University of Life Sciences, Ås, Norway, 2009.

91. Vedeld, P.; Cavanagh, C.; Petursson, J.G.; Nakakaawa, C.; Moll, R.; Sjaastad, E. The political economy of conservation at Mount Elgon, Uganda: Between local deprivation, regional sustainability, and global public goods. Conserv. Soc. 2016, 14, 183. [CrossRef]

92. Lang, C.; Byakola, T. "A Funny Place to Store Carbon": Uwa-Face Foundation's Tree Planting Project in Mount Elgon National Park, Uganda; World Rainforest Movement: Montevideo, Uruguay, 2006.

93. Cavanagh, C.; Benjaminsen, T.A. Virtual nature, violent accumulation: The 'spectacular failure'of carbon offsetting at a Ugandan National Park. Geoforum 2014, 56, 55-65. [CrossRef]

94. McLean, J. Conservation and the impact of relocation on the tharus of Chitwan, Nepal. J. Assoc. Nepal Himal. Stud. 1999, 19, 8 .

95. McLean, J.; Straede, S. Conservation, relocation, and the paradigms of park and people managementA case study of padampur villages and the Royal Chitwan National Park, Nepal. Soc. Nat. Resour. 2003, 16, 509-526. [CrossRef]

96. Mount Elgon Violations. Uganda Human Rights Network. Available online: https://www.youtube.com/ watch?v=OlDTRSO9exY (accessed on 25 May 2018).

97. Young, I.M. Polity and group difference: A critique of the ideal of universal citizenship. Ethics 1989, 99, 250-274. [CrossRef]

98. Honneth, A. Recognition and justice: Outline of a plural theory of justice. Acta Sociol. 2004, 47, 351-364. [CrossRef]

99. Gebara, M.F.; Agrawal, A. Beyond rewards and punishments in the brazilian amazon: Practical implications of the REDD+ discourse. Forests 2017, 8, 66. [CrossRef]

100. Paavola, J.; Adger, W.N. Fair adaptation to climate change. Ecol. Econ. 2006, 56, 594-609. [CrossRef]

(C) 2018 by the authors. Licensee MDPI, Basel, Switzerland. This article is an open access article distributed under the terms and conditions of the Creative Commons Attribution (CC BY) license (http:/ / creativecommons.org/licenses/by/4.0/). 